International Journal of Instruction e-ISSN: 1308-1470 • www.e-iji.net

Article submission code: 20191129220020

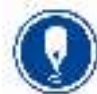

January $2021 \bullet$ Vol.14, No.1

p-ISSN: 1694-609X

pp. 325-344

Received: 29/11/2019

Revision: 23/06/2020
Accepted: 13/07/2020

OnlineFirst:18/10/2020

\title{
Students' Perceptions of Collaborative Team Teaching and Student Achievement Motivation
}

\author{
Khoirul Anwar \\ Dr., University of Muhammadiyah Gresik, Indonesia, khoirulanwar@umg.ac.id
}

Slamet Asari

University of Muhammadiyah Gresik, Indonesia, asari70@umg.ac.id

Rohmy Husniah

University of Muhammadiyah Gresik, Indonesia, rohmyhusniah@umg.ac.id

\section{Candra Hadi Asmara}

University of Muhammadiyah Gresik, Indonesia, candrafkip@umg.ac.id

\begin{abstract}
To date, only student's collaborative behaviour in learning is seen and linked to achievement motivation. Even though the teacher has a great role to determine learning process, only few research findings link collaborative teacher to student learning motivation. This study aims to identify predictions of correlation between students' perceptions of collaborative team teaching (a collaborative role between teacher and lecturer) in a high school of a remote area with their learning motivation. This study uses survey and correlational design with two questionnaires namely students' perceptions of collaborative team teaching (with average validity level of $\mathrm{r} 0.85$ and reliability of 0.972 ) and about learning motivation (with average validity level of $\mathrm{r} 0.65$ and reliability of 0.899 ). These two measured-valid questionnaires were distributed to all participants, of 50 respondents and then analysed using Pearson correlation. The results showed that the calculated $\mathrm{r}$ was 0.568 and the significant value of 0.003 , so it could be predicted that students' perceptions on collaborative team teaching were significantly and strongly correlated to learning motivation. This research proves that students have professed highly on collaborative team teaching for teachers to team up with various external parties (especially with lecturers) and regarded advantageous on achievement motivation of students. This study also confirmed that learning strategies must be selective and collaboratively designed to fit the learner's expectancy so that they can activate self-image and future self-image to elevate learning motivation.
\end{abstract}

Keywords: achievement motivation, collaborative team teaching, teacher teaching collaboration, teaching, students

Citation: Pasetto, S. C., Barreiros, J. M. P., Corrêa, U. M., \& Freudenheim, A. M. (2021). Students' Perceptions of Collaborative Team Teaching and Student Achievement Motivation. International Journal of Instruction, 14(1), 325-344. https://doi.org/10.29333/iji.2021.14119a 


\section{INTRODUCTION}

Study of achievement motivation is always associated with how great the role of individual learners gets optimal space in partnership learning. However, not many studies have suggested the importance of teacher collaboration connected to the student learning motivation itself (Asari, Husniah, Ma'rifah, \& Anwar, 2019). There are three areas where collaboration and motivation are always sought in the field of English education (Anwar \& Wardhono, Students' Perception of Learning Experience and Achievement, 2019). Firstly, student learning collaboration is usually associated with student motivation where this search generally emphasizes the impact of applying collaborative learning for student achievement motivation that leads to learning experiences, learning processes, and learning expectations. Secondly, teacher teaching collaboration is linked to teacher motivation. This search focuses merely on its impact on the success of teachers in teaching collaboratively with the motivation of the teacher himself in developing his career as a professional teacher. Thirdly, teacher's collaborative team teaching is associated with student achievement motivation. This type of study produced many ideas about the importance of maintaining student motivation through teacher collaborative work with colleagues and external parties such as universities, education practitioners, school communities, etc.

Studies recently are still mainly on the first and second area above, not many have put forward the search for the impact of the application of collaboration by teachers on student achievement motivation in broader scope. Students and teacher achievement motivation factually is still interpreted only to focus on student learning experiences with fellow students, conversely teacher motivation is also still seen in the teacher's experience to handle collaborative learning with fellow teachers (Asari, Husniah, Ma'rifah, \& Anwar, 2019). It turns out that the challenges of handling future teaching may not be resolved with the teacher himself, but it requires close and good cooperation with external parties, especially lectures in universities.

In the context of Indonesia, English teacher collaboration with external parties (especially lectures) is quite hard to realize because there are many inhibiting factors, among others;

1. Limitations of forum that periodically allows teachers to share their internal problems through workshops and seminars that involve many external stakeholders (Anwar, Asari, Fauziyah, Arifani, \& Suryanti, 2019).

2. Limited access to cooperation with external parties, especially universities to deal with problems in the classroom.

3. Limited authority of the teachers to decide teaching strategies independently without feeling constrained by administrative affairs that block and slows the growth of the learning process to suit students' needs (Anwar \& Wardhono, Students' Perception of Learning Experience and Achievement, 2019).

Of the three factors, the third point above is greatly relevant to be followed up in this paper because the decision on choosing a teaching strategy that suits the needs of 
learners is urgently needed. This is because the demands of English learning are increasingly high due to the diverse and varied speed and dynamics of student learning needs (Anwar \& Arifani, Task Based Language Teaching: Development of CALL, 2016). Rapid changes and development of civilization entail change treatments preferably to all forms of service in the era of today English education and in the future. The acceleration of this change results a shift in handling the problems faced by English teachers at classroom (Berwick, 1989). Maybe in the past, the problem of learning English was dominated by teacher and students, but now the problem is growing rapidly towards updating strategies that are able to integrate learning media which is up to date to meet students' learning needs periodically and continuously so that teachers are required to bring the learning process easier and faster to be digested by students (Asmara, Anwar, \& Ribeh, 2016).

Among the tangible conditions that challenge English teaching in Indonesia is the lack of time for teachers to update their knowledge for current learning concepts and strategies because they are dominantly preoccupied by irresistible administrative procedures. On the other hand, the success of teachers which are still measured in quantitative ways make another affliction for them (Conole, 2013). There must be natural program to relief and to reduce the teachers' difficulties by sharing responsibility that the success of teaching is collaborative to other parties such as the curriculum designers, students, learning program leaders, and also other groups outside the school who have similar roles. Another challenge is to embrace convenience learning interactions at school environment which are driven by the optimization of teacher as a learning facilitator, so that students driven with full awareness can direct their optimal abilities to achieve learning success (Anwar, 2015).

All educational service processes provided by all teachers must also have an impact on students as objects as well as subjects of learning. The most visible impact is on student achievement motivation which must also grow because one of the ultimate goals of changes and selection of teaching strategies is increasing student motivation (Cerino , 2014). Moreover, for students in remote areas such as Bawean Island, besides the limitations on the availability of time and access of teachers to improve the quality of their teachings, the problem of learning motivation of students is still very unlikely and rarely touched. This is reasonable because regions like this have other important priorities to be fulfilled, especially to realize basic needs of education such as the availability of teachers, facilities, revitalization of curriculum, funding, etc.

Therefore this study aims to see (1) students' perceptions of collaborative team teaching that has been carried out (2) Student perceptions of their achievement motivation (3) Correlation between perceptions of collaborative team teaching and their achievement motivation in high school of Mambaul Falah Bawean, Gresik, Indonesia.

\section{Literature Review}

\section{Collaborative team teaching for High School Teachers at a Remote Area}

Seeing the real conditions encountered by most teachers to look unpredictable conditions and demands that are so dynamic, especially at the current high school level 
at remote areas, adjustments to reduce their problems that arise at any time require special methods with particular treatments (Anwar \& Arifani, 2016). More specifically the problem of teaching English for regions that have limited access to the availability of media and the means of learning they have. So it takes the role of external parties, especially universities, to help ease the burden and reduce their problem of English teachers. One effort to alleviate the burden of the English teachers in remote areas is to help them make a partnership by assigning lecturers to schools with the aim of conducting collaborative team teaching with English teachers (Asmara, Anwar, \& Ribeh, 2016).

Through the lecturer teaching program in schools in this remote area (Bawean island), school generally can at least take advantages of this opportunity to:

- $\quad$ Plan teaching English together and collaborate in maximizing the resources available at school.

- Implement a learning process that prioritizes collaborative team teaching or teaches with the lecturers to manage learning that meets the rules of teaching quality more easily (Conole, 2013).

- Implement evaluation of learning continuously and periodically so as to be able to see things that are the strengths and weaknesses of each process and look for opportunities for continuous improvement.

Those three areas are part of important actions to tackle common problems they face so far (Conole, 2013). Of course, many studies especially previous researchers state that teaching problems are in the common three areas, namely planning, teaching implementation, and evaluation. When viewed carefully, of course the estuary of the three problems is on the teachers themself because he/she has a strong role to change and direct every process in the class in order to achieve the desired learning goals which is in accordance with the basic competencies being planned (Alireza, Gholamreza, \& Samaneh, 2012).

The optimism of collaboration and partnership between teachers and lecturers to the area of implementation is certainly a virtuous effort but certainly not easy (Johnson, 2012). Many cases prove that not many teachers have a strong desire to collaborate and work with other parties, especially the lecturers to teach together in class and help each other evaluate the process. This reluctance is reasonable because teachers are not used to evaluating each other when teaching. So far the teacher is a central figure who is assumed to be very capable of planning, implementing, and evaluating the achievement of lessons in his/her own class. So that if there is involvement of other parties it is considered to be an additional load in learning process at classroom (Shiri, 2015).

Thus, the implementation of collaborative teaching requires more qualified teachers with their strong willingness and commitment to build a positive or an effective collaboration among them (Friend \& Cook, 2007). As defined by Murawski (2010) who views that collaboration is a way of an interaction where two or more professionals work together to achieve a particular objective (Murawski, 2010). These professionals engage in 
shared problem solving and decision making regarding planning, excecuting, and reflecting the teaching and learning they deal with. A study done by Zhou, George \& Jinyoung, KIM \& Judit, Kerekes (2011) found that "collaborative teaching was a reciprocal learning process where teachers were engaged in thinking about teaching in a broader and innovative way". Other studies indicated that collaborative teaching is very useful and fruitful for teachers. Collaborative teaching gives them chances to get involved in more philosophical discussions and to learn more about experiences and way of teaching one to another (Letterman \& Dugan, 2004; Robinson \& Schaible, 1995).

The concept of collaborative team teaching has certainly been completed by teachers who have open access to the world outside of school (Asmara, Anwar, \& Ribeh, 2016). Many of specific benefits for teachers from this process include:

- Changing the teacher's mind set becomes more open in dealing with and solving every problem of learning English in the classroom so that it is easy to solve by frequently involving colleagues and friends of the same profession to get new ideas through focus group discussions.

- The teacher can anticipate and periodically evaluate the achievement of standard competencies.

- Being an effective place for resource sharing between involved stakeholders, especially all parties internally and externally, resulting in a collective awareness that the progress and success of learning English is the responsibility of all stakeholders involved.

The main capital of collaborative team-teaching success in learning English is of course there should be existing manifestation of emotional and intellectual maturity (Tibbetts, Canning, \& Harackiewicz, 2015; Zhou, KIM, \& Kerekes, 2011; lim \& Kwiatkowski, 2018). Intellectual maturity alone is not sufficient because cooperation requires emotional maturity as well especially in terms of building communication to trust each other, be positive, and build a good atmosphere. The advantage built from this process is the growth of positive learning spirit that occurs both by the collaborative of teachers who always update their knowledge as well as students who are studying. Thus, if these two parties turn out to be one goal, it will be easy to face every difficulty and challenge that arises in the midst of changes and developments of science and technology lately that affect shifting needs of students in learning English. The combination of these goals is needed specifically for teachers who are teaching in remote areas, namely Bawean Island, that of course do not have much greater access compared to those who teach in urban areas. Assistance for them is very indispensable because it firmly deliberates all contemporary difficulties and challenges that might always be organized discretely.

\section{Motivation in learning English}

There are two desired outcomes in the implementation of this collaborative team teaching, namely increasing teacher enthusiasm and student motivation in taking English learning in the classroom. Motivation is an innate feature that is influenced by four 
factors, namely the situation (environment and external stimulation), mood (mental state and emotional organisms), goals (behavioral goals and tendencies), and tools (for achieving goals) (Dornyei, 1994). Self-motivation is divided into two types, namely the ideal of self and ought to self, where the first relates to the representation of one's attributes (representation of hopes, aspirations, and desires), while the second is related to the attributes of someone which should be owned (e.g. responsibility, representation of how you work, etc.) (Klimova, 2011). Humans get the motivation needed to fulfill their goals, needs, or instincts. In the view of education, motivation is a multifaceted structure that is related to learning and academic achievement. Educational motivation is seen as a three-dimensional concept consisting of a series of individual beliefs about the abilities, intentions, and relevant emotional responses needed to display certain activities (Shiri, 2015). Experts believe motivation is of two types: intrinsic and extrinsic motivation. Intrinsic motivation creates an attraction for someone to act or react in a certain way, while extrinsic motivation arises as a result of influences from outside sources that encourage someone to act intentionally. Psychologists have emphasized the importance of motivation in learning new skills, strategies, and behaviors, and have proposed academic achievement motivation as one of the main factors needed to achieve a more accurate definition of motivation. Motivation for academic achievement refers to behaviours that produce learning and (academic) achievement (Alireza, Gholamreza, \& Samaneh, 2012).

Motivation is considered a key concept in both psychology and language education (Karami, Pakmehr, \& Aghili., 2015). Those who care about education, including teachers, students and parents, mostly use the term to explain the success or failure of students in the implementation of education. Indeed, language learners need motivation to provide a big impetus to start learning languages and then rely on motivating power to continue the process of learning the next language (liu, 2015). The traditional concept still views motivation as an effort to increase learners who have not or are not even motivated at all to be motivated (My Lien, 2009). But recently, however, many researchers have led to research into motivations that come into contact with strategies and have implications for learning so that many are able to contribute to the progress of their theories in learning practices especially in better methodologies (HamzaouiElachachi \& Graia, 2014). Even today there are many motivational studies that have led to the quality of learning in the classroom. So the results of motivational studies that lead to improving the quality of this class have helped expand this study of motivation towards cognitive motivation, the need for achievement, and also related to other situational factors such as class characteristics and language teachers (Shiri, 2015).

The concept of learning by combining alternative sharing in the form of collaborative team teaching (that is, involving lecturers in universities to be directly involved in teaching in schools on Bawean Island) can provide greater opportunities for equal access and opportunities to ease the burden on teachers in achieving the standards of learning competency (Anwar, A Constructive Teaching Model in Learning Research Concept for English Language Teaching Students, 2015). To ensure that the collaborative team teaching and learning model by the school lecturers and teachers have a real impact on the high school in remote areas on Bawean Island, this research 
attempts to find out students' perceptions of the learning methods that have been implemented during collaborative team teaching and how are their motivation to achieve success in learning.

\section{METHOD}

\section{Research Design}

This study is sought to find out the relationship between student perceptions about collaborative team teaching and learning models with learning motivation. The collaborative team-teaching model was conducted between lecturers of English language education at the University of Muhammadiyah Gresik and the teachers at Mambaul Falah high school on Bawean Island. This study certainly wants to ensure that after the collaborative team-teaching process is carried out whether it can be detected and predicted to correlate with students' motivation in achieving better performance.

Thus the design chosen was correlational research using two types of questionnaires, namely a questionnaire about student perceptions in collaborative team teaching and learning and the second was a student perception questionnaire about learning motivation.

\section{Research Respondents and Data Collection}

Two questionnaires were distributed to 50 respondents in Madrasah Aliyah Mambaul Falah (Islamic Senior High School) who were all participants who had contributed in collaborative team teaching and learning by teachers and lecturers. This school is the only one that has been accredited A (superior) and is the best school of the other comparable six Madrasah in the island of Bawean. Profile of respondents in this study is the ninth-grade students consisting of 35 girls and 15 boys with ages ranging from 16 to 18 years. All respondents have a rural background with two languages, namely Bahasa Indonesia and a regional language, Baweanese (see table 1).

Table 1

Profile of respondents

\begin{tabular}{ll}
\hline Items & Description \\
\hline Sex & 35 female \\
& 15 male \\
\hline Age range & $16(10$ respondents $)$ \\
& $17(28$ respondents $)$ \\
& $18(12$ respondents $)$ \\
\hline Education level & Senior high school \\
\hline Social status & rural \\
\hline Language of common use & Bahasa Indonesia, Baweanese \\
\hline
\end{tabular}

After the data is collected using the two questionnaires, then it was analysed descriptively. 


\section{Research Instrument}

The research engages two questionnaires wherein the student questionnaire about the perception of collaborative team teaching and learning contains 15 items to explore information on the context of learning implementation in three aspects, namely skills, knowledge, and learning process. While the questionnaire about students' perceptions of motivation to learn there are also 15 items that contain encouragement for achievement and their made efforts. These two questionnaires have also been tested for their validity and reliability to ensure the feasibility of the instrument in this study.

Analysis of validity and reliability about students' perceptions of collaborative team teaching

As a short depiction, the student perception questionnaire about the application of teacher learning methods consists of skills, knowledge, and the learning process itself (Hariyanto, Dewi, \& S, 2014). Learning skills are related to explaining ability to use methods that facilitate student understanding (items 1 to 3).The aspect of knowledge is the teacher's ability to explain the material in accordance with the given time limit and the correct and easily understood way of explanation (items 4 to 7.The aspect of the learning process consists of choosing the right method, clarity in giving information, giving the opportunity to ask questions and the opportunity to answer questions (items 8 to 15$)$.

The results of the analysis of the validity of the questionnaire about teaching application method shows that based on the calculated $\mathrm{r}$ analysis, it is obtained that item 1 is 0.877 , item 2 is 0.816 , item 3 is 0.839 , item 4 is 0.820 , item 5 is 0.787 , item 6 is 0.831 , item 7 is 0.922 , item 8 of 0.772 , item 9 of 0.848 , item 10 of 0.897 , item 11 of 0.913 , item 12 of 0.859 , item 13 of 0.892 , item 14 of 0.832 , and item 15 of 0.867 . Thus questions number 1 to 15 are valid because there are no analysis results that are under 0.3 .

The reliability analysis of the questionnaire about the application of the teaching method was carried out using the Cronbach's alpha study as follows:

Table 2

Reliability statistics of questionnaire about collaborative team teaching

\begin{tabular}{ll}
\hline Cronbach's Alpha & $\mathrm{N}$ of Items \\
\hline .972 & 15
\end{tabular}

The results of the reliability analysis show that the value of Cronbach's Alpha is 0.972 where this number is greater than the minimum score of 0.6. This means that the instrument questionnaire used to measure students' perceptions is valid and reliable.

\section{Validity and Reliability; Analysis Questionnaire about achievement motivation}

The questionnaire about achievement motivation was also compiled into 15 items which overall contained the drive for achievement and efforts to achieve (Alireza, Gholamreza, \& Samaneh, 2012). The drive for this achievement has seven aspects, namely the learning objectives to be achieved as many as 2 items, namely 1 and 2 , self-confidence as many as two items, namely 3 and 4, relationships have three items, namely 5, 6 and 7, 
pride with two items, 8 and 9, accepting assignments with two items, 10 and 11, responsibility with two items, 12 and 13, and willingness to accept risks, items 14 and 15.

The results of the validity analysis indicate that the number of calculated $\mathrm{r}$ for each item is item 1 of 0.742 , item 2 is 0.777 , item 3 is 0.684 , item 4 is 0.792 , item 5 is 0.504 , item 6 is 0.673 , item 7 is 0.539 , item 8 amounting to 0.559 , item 9 amounted to 0.712 , item 10 was 0.700 , item 11 was 0.665 , item 12 was 0.603 , item 13 was 0.714 , item 14 was 0.436 , and item 15 was 0.601 .These analyses and calculations show that all items are in positions above 0.3 where all items (15 items) are considered valid.

Furthermore, the results of reliability analysis are described as follows:

Table 3

Reliability statistics of questionnaire about achievement student

\begin{tabular}{ll}
\hline Cronbach's Alpha & N of Items \\
\hline .899 & 15 \\
\hline
\end{tabular}

The value of the analysis using Cronbach's Alpha shows 0.899 where this number has been in a position above 0.6 which means that all items in the perception questionnaire about student learning motivation have been reliable.

\section{Data Analysis}

This study uses two types of analysis namely descriptive statistics and the Pearson Product Moment formula. Descriptive statistics are required to define perceptions about the collaborative implementation of the team teaching model and description of the level of achievement motivation. The Pearson Product Moment formula is used to analyse the prediction level of correlation obtained from opinions about the implementation of collaborative team teachings with achievement motivation.

\section{RESULTS}

\section{The Results of Student Perception About Collaborative Team Teaching}

Collaborative team teaching is a concept of teaching that has been carried out by three lecturers from University of Muhammadiyah Gresik and two teachers who are at Mambaul Falah Madrasah Aliyah (High School) in Bawean, Gresik Regency of Indonesia. This teaching collaboration has been held for ten meetings from August to October 2018. The learning process briefly uses a Plan, Do, and See pattern together between college lecturers and teachers at the school. In the Plan stage, all instructors discuss to plan together what will be taught, methods to be used, strategies and learning procedures that will be implemented, and also student evaluations to be optimized. This stage asks the school teacher to describe all problems, especially the shortcomings of teaching services at the class, then collaboratively arrange differently or new teaching offers that are expected to provide a new atmosphere. The stage of Do is teaching implementation where the lecturers alternately become a model teacher who applies classroom learning by asking other members to become observers, especially monitoring the process to be optimal and recording the problems and progress of students in 
attending classes. The stage of See is an evaluation together with the ultimate goal is to see the lack of implementation of classroom learning and to give input to the next learning process in order to have next better teaching plan. These processes are up to ten meetings so that of each stage, the teacher can specifically maximize opportunities to discuss with lecturers to solve all class problems related to direct teaching supports such as media, material, and other learning resources, and indirectly including the application of the latest learning strategies from various references that have been introduced by the lecturers. After this collaborative team teaching was completed, students were asked to fill out a questionnaire in which the results of the description are in Table 4 below.

Table 4

Descriptive statistics of student perception about collaborative team teaching

\begin{tabular}{|c|c|c|c|c|c|c|}
\hline No & Items & $\mathrm{N}$ & Min & Max & Mean & Std. Deviation \\
\hline 1. & $\begin{array}{l}\text { The teachers use learning methods that are easily to } \\
\text { follow. }\end{array}$ & 50 & 2.00 & 5.00 & 3.4800 & .71414 \\
\hline 2. & $\begin{array}{l}\text { In collaborative team teaching and learning activities, the } \\
\text { teachers explain the material in sequence. }\end{array}$ & 50 & 2.00 & 5.00 & 3.2000 & .91287 \\
\hline 3. & $\begin{array}{l}\text { The collaborative team-teaching method made me focus } \\
\text { more on listening to the material given }\end{array}$ & 50 & 2.00 & 5.00 & 3.2400 & .87939 \\
\hline 4. & $\begin{array}{l}\text { The teachers adjust the method used in the lesson to suit } \\
\text { with time, class conditions, and subject matter }\end{array}$ & 50 & 2.00 & 5.00 & 3.3200 & .90000 \\
\hline 5. & $\begin{array}{l}\text { In collaborative team teaching, English teachers also } \\
\text { provide motivation about subject matter that is suitable } \\
\text { for everyday life }\end{array}$ & 50 & 2.00 & 5.00 & 3.4400 & .71181 \\
\hline 6. & $\begin{array}{l}\text { In collaborative team teaching, English teachers also } \\
\text { provide general knowledge to students }\end{array}$ & 50 & 2.00 & 5.00 & 3.4800 & .82260 \\
\hline 7. & $\begin{array}{l}\text { English teachers provide knowledge by linking lessons to } \\
\text { everyday life }\end{array}$ & 50 & 2.00 & 5.00 & 3.3600 & .75719 \\
\hline 8. & The teachers always give homework or assignments & 50 & 2.00 & 5.00 & 3.4400 & .76811 \\
\hline 9. & $\begin{array}{l}\text { By various procedures in collaborative team teaching, I } \\
\text { easily understand the subject matters more. }\end{array}$ & 50 & 2.00 & 5.00 & 3.4800 & .71414 \\
\hline 10. & The teachers give summarizing task to the students. & 50 & 2.00 & 5.00 & 3.4400 & .82057 \\
\hline 11. & $\begin{array}{l}\text { The collaborative team-teaching method used by English } \\
\text { teachers makes the lesson more interesting and easier to } \\
\text { understand. }\end{array}$ & 50 & 2.00 & 5.00 & 3.4400 & .71181 \\
\hline 12. & $\begin{array}{l}\text { The method of collaborative team teaching made me } \\
\text { enthusiastic about learning. }\end{array}$ & 50 & 2.00 & 5.00 & 3.5600 & .76811 \\
\hline 13. & $\begin{array}{l}\text { The collaborative team-teaching method makes me not } \\
\text { bored. }\end{array}$ & 50 & 2.00 & 5.00 & 3.4400 & .82057 \\
\hline 14. & $\begin{array}{l}\text { The teachers always give students the opportunity to ask } \\
\text { questions }\end{array}$ & 50 & 2.00 & 5.00 & 3.4400 & .82057 \\
\hline \multirow[t]{2}{*}{15} & The teachers always answer student questions clearly. & 50 & 2.00 & 5.00 & 3.1200 & .88129 \\
\hline & Average & 50 & 2 & 5 & 3.4 & .800 \\
\hline
\end{tabular}

The data above shows that the average student believes that the implementation of collaborative team teaching is acceptable and worthy for ten meetings with the scale level is 3.4. This means that students share an agreement on the implementation of collaborative team teaching in their school. 


\section{The Results of Student Perception about Achievement Motivation}

After the learning process for ten meetings, the questionnaire on achievement motivation was also given to all participants who participated in the collaborative team-teaching program. As explained in the previous section, achievement motivation is needed to ensure the true picture of student affection during the program. This motivation is very important in order to optimize the next education service so that students can feel the best experience while studying at school. The results of the description about achievement motivation of students can be seen in table 5 below.

Table 5

Descriptive statistics of achievement motivation

\begin{tabular}{|c|c|c|c|c|c|c|}
\hline No & Items & $\mathrm{N}$ & Min & Max & Mean & Std. Deviation \\
\hline 1. & I want to get a high level of English. & 50 & 2.00 & 5.00 & 3.0800 & .75939 \\
\hline 2. & I want to get the best rank in the class really. & 50 & 2.00 & 4.00 & 3.1200 & .72572 \\
\hline 3. & $\begin{array}{l}\text { I can definitely achieve the highest score in } \\
\text { English lessons. }\end{array}$ & 50 & 2.00 & 4.00 & 2.8400 & .55377 \\
\hline 4. & $\begin{array}{l}\text { I can definitely achieve higher achievements than } \\
\text { other friends. }\end{array}$ & 50 & 2.00 & 4.00 & 2.9600 & .73485 \\
\hline 5. & $\begin{array}{l}\text { I was able to complete the tasks given by the } \\
\text { teacher as well as possible. }\end{array}$ & 50 & 2.00 & 4.00 & 3.0000 & .57735 \\
\hline 6. & $\begin{array}{l}\text { I feel able to compete to get maximum results in } \\
\text { English lessons. }\end{array}$ & 50 & 2.00 & 4.00 & 3.1200 & .78102 \\
\hline 7. & $\begin{array}{l}\text { I always complete tasks without the help of } \\
\text { friends. }\end{array}$ & 50 & 2.00 & 4.00 & 3.1200 & .60000 \\
\hline 8. & Achieving high grades is my pride. & 50 & 2.00 & 4.00 & 2.9600 & 61101 \\
\hline 9. & $\begin{array}{l}\text { I am happy if other people congratulate me on } \\
\text { my achievements. }\end{array}$ & 50 & 2.00 & 5.00 & 3.0000 & .76376 \\
\hline 10. & $\begin{array}{l}\text { I am always eager to face the challenges of } \\
\text { learning. }\end{array}$ & 50 & 2.00 & 4.00 & 3.1600 & 68799 \\
\hline 11. & I will finish my schoolwork as well as possible. & 50 & 2.00 & 5.00 & 3.1200 & .78102 \\
\hline 12. & I will be responsible for all my actions at school. & 50 & 2.00 & 4.00 & 3.2400 & .66332 \\
\hline 13. & $\begin{array}{l}\text { I will work on the questions during the exam } \\
\text { without the help of others. }\end{array}$ & 50 & 2.00 & 5.00 & 3.1200 & .66583 \\
\hline 14. & $\begin{array}{l}\text { I am worried about my current performance if I } \\
\text { do not maintain it. }\end{array}$ & 50 & 2.00 & 5.00 & 3.3200 & .80208 \\
\hline 15. & $\begin{array}{l}\text { Failure in learning achievement will not weaken } \\
\text { my enthusiasm to move forward. }\end{array}$ & 50 & 2.00 & 3.00 & 2.8000 & .40825 \\
\hline & Average & 50 & 2 & 5 & 3.06 & .700 \\
\hline
\end{tabular}

The data shows that learning motivation in terms of strong expectations in obtaining achievement is at level 3 meaning they agree and are determined that the expectations for achievement are well-owned by all students. Likewise, when it comes to the process of gaining achievement, it is also at level 3 where students have a strong awareness to undergo the proper process when they have expectation of achieving gains naturally and well.

\section{The results of Correlation Analysis}

This section describes the prediction of the relationship between students' perceptions of the implementation of collaborative team-teaching programs with achievement 
motivation. This relationship prediction is very important to ensure that affective factors in learning, especially changes in learning strategies undertaken by schools, are strongly related to students' learning motivation in gaining achievement.

The essential concern of formulation of this research hypothesis is detailed in this segment. Teachers must deliver learning strategies to inspire students' potential emotionally with positive self-concepts. Thus the teacher learning strategy is to establish closer teacher and student relations that enhance better achievement motivation (Awan, Noureen, \& Naz, 2011). As it is known that perceptions of achievement motivation are supported by three theories, namely, learning drive theories oriented towards approval, ownership, and achievement motives, Cognitive Attribution Theories that emphasize the quality of tasks to drive performance in achievement, and Self-worth Theory that prioritizes self-competence or ability as a prime mover in achievement behaviour (Covington, 1984). Furthermore, students' self-confidence and motivation in learning are influenced by three important entities, namely tasks and learning activities tinted by collaboration, adequate recognition of student involvement, and educative evaluation. All three certainly encourage the orientation of better student learning goals (Alderman, 2004). Collaborative team teaching is able to offer more optimal learning climate because the positive environment can raise the perception growth to help create excelled learner's personality (Han \& Lynch , 2014). This positive perception of the learning climate places the highest priority on encouraging high academic achievement. Collaboration or team teaching can induce learning achievement and motivation because learners can get enough space to elevate opportunities for interaction more optimally (Shachar \& Fischer, 2004). Collaborative team-teaching strategies award examples of peer-to-peer teaching and learning relationships that respect each other to provide academic plot for appreciation and automatically boost positive perceptions of student achievement motivation (Nelson \& DeBacker, 2008).

The justification above is adequate to ascertain that there is sufficient estimate of correlation between the employments of collaborative team teachings with student achievement motivation. As usual this section then begins by testing the null hypothesis statement as follows:

Ho: There is no significant relationship between students' perceptions of collaborative team teaching programs with achievement motivation in learning

Hi: There is a significant relationship between students' perceptions of collaborative team teaching programs with achievement motivation in learning

The results of the Pearson correlation test are in Table 6 as follows: 
Table 6

Correlations

\begin{tabular}{llll}
\hline & & $\begin{array}{l}\text { Perceptions of } \\
\text { Collaborative team } \\
\text { teaching }\end{array}$ & $\begin{array}{l}\text { Perceptions of Achievement } \\
\text { Motivation in Learning }\end{array}$ \\
\hline $\begin{array}{l}\text { Perceptions of } \\
\text { Collaborative } \\
\text { team teaching }\end{array}$ & Pearson Correlation & 1 & $.568(* *)$ \\
\cline { 2 - 4 } & Sig. (2-tailed) & $\mathrm{N}$ & .003 \\
\cline { 2 - 4 } $\begin{array}{l}\text { Perceptions of } \\
\text { Achievement } \\
\text { Motivation in } \\
\text { Learning }\end{array}$ & Pearson Correlation & $.568(* *)$ & 25 \\
\cline { 2 - 4 } & Sig. (2-tailed) & .003 & 1 \\
\hline
\end{tabular}

** Correlation is significant at the 0.01 level (2-tailed).

Correlation test results show that calculated $\mathrm{r}$ of 0.568 where this value is greater than 0.5 with its $\mathrm{p}$ value is 0.003 , thus the null hypothesis is statistically rejected. It means that there is a significant (0.003), positive, and strong correlation (0.568) of the two variables between students' perceptions of the application of collaborative team-teaching methods and achievement motivation expected by students.

\section{DISCUSSION}

The results of this study certainly support many previous studies (My Lien, 2009; Tibbetts, Canning, \& Harackiewicz, 2015; Bao \& Lee) which suggest that the learning process that is well prepared will affect high quality of learning process. Of course the quality of this learning is perceived in two big areas by students, namely the quality in terms of output achievement and quality with regard to aspects of satisfaction (affective).The output of learning outcomes is certainly related to the increasing score of learning achievement itself, while the aspect of satisfaction is often identical with affective learning satisfaction including the expectation of desired achievement.

As explained earlier in this paper, the pattern used in the implementation of learning strategies by lecturers who teach at the high school level is done in an optimal collaboration with English teachers in Madrasah Aliyah Mambaul Falah Bawean. This collaboration starts from planning, implementing and evaluating learning. The planning stage requires the involvement of teachers and lecturers in producing a learning plan that includes the use of materials and methods designed to best suit the classroom situation. After that they are collaboratively implementing the plan in the classroom in the form of collaborative team teaching. Likewise, when evaluating learning, they collaboratively also correct the current and ongoing processes and evaluate the test tools to measure the desired learning outcomes in accordance with their achievements.

Because the process is carried out collaboratively with the teacher by collaborative team teaching, this kind of process is very helpful to contribute well to tackle teaching problems of English at the high school level (Zhou, KIM, \& Kerekes, 2011). As we all know that the problem of learning in high schools is always identical with three major areas, namely teacher problems, media problems, and student problems. Teacher 
problems often relate to the lack of time available to innovate through their involvement in scientific forums which are expected to provide benefits in planning and implementing better learning in the classroom. Likewise, the limited time in the planning is also further impacts to the burdens of teaching too much so that almost all opportunities to make learning innovations are not optimal. Additionally, the media problem is always associated with the learning facilities accessible in schools. Whereas this learning media is part of the teacher's authority and the results of the teacher's creativity to achieve optimal efforts in conveying the materials and method of teaching appropriately and well (Vicente, Tan, \& Yu, 2018). Meanwhile, the problem of students is identified with their low ability to follow the learning process. In summary, the problem of the low ability of students in learning is more due to the lack of optimal materials, methods and learning media in a limited time applied in the classroom. The less optimal implementation of those things are more due to the limitations of teachers in innovating and learning creatively. Therefore by helping teachers in planning and implementing collaborative learning processes in the classroom by direct assistance in the form of collaborative team teaching, of course it can encourage teachers to optimize their proper role in teaching English better (Anwar \& Arifani, Task Based Language Teaching: Development of CALL, 2016).

The common term used in teacher teamwork for planning and implementing teaching by involving other parties is also called a collaborative system (Vicente, Tan, \& Yu, 2018). Many educators have emphasized that effective teachers are those who set clear learning strategies and encourage students to interact with their classmates during the group process by giving them team building exercises, collaborative norm formation, and clear team structure specifications. Based on the research there are five important pillars needed to build the foundation of effective collaborative and collaborative experience, namely: positive interdependence, promotive interaction, individual accountability, social skills, and group processing (Falls, Bahhouth, Chuang, \& Bahhouth, 2014). Collaborative or collaborative team teaching is a reciprocal learning process in which all are involved in thinking about teaching in a broader and innovative way. Collaborative work is defined as two or more people working together and optimizing their potential in solving problems (Zhou, KIM, \& Kerekes, 2011). So any collaborative intellectual work efforts carried out by teachers or students are part of collaborative learning both in writing or collaborative project work (Vicente, Tan, \& Yu, 2018). Among the common characteristics of collaborative work is solving complex tasks into easy parts; plan and arrange the right time; discussions and explanations are used to equate understanding; give and receive feedback about performance; Promote consumption; develop communication skills (Pateșan, 2017). In addition to collaborative, the meaning of collaborative team teaching can also lead to co-teaching, especially those often done in medical study programs. Co-teaching has been suggested as a means to integrate the contents of the medical school curriculum. Because there is limited evidence about the lecture method. Co-teaching is generally used in small groups of learners, where this method is applied to problem-based and team-based learning sessions, or as a means to integrate basic science (Lim \& Kwiatkowski, 2018). Many studies show that co-teaching 
enhances the ability to apply basic science to clinically relevant problems (Willey, lim, \& Kwiatkowski, 2018).

This study shows that collaborative team teaching optimistically supports the study of student achievement motivation in learning English. In essence, motivation is an important activity to achieve the success of learning competencies. Visible motivated behavior is energetic, sustainable and oriented. In this case, academic motivation not only creates interest in learning but also helps in achieving academic achievement (Kharameh, Sharififard, Asayesh, Sepahvandi, \& Hosein, 2018). Motivation is very agreed upon as an encouragement to inspire people to learn, direct and strengthen them to invest some efforts to achieve their goals (Rezvani, Pakdaman, \& Bigdeli., 2015). Dörnyei (2003) proposes a dynamic picture of motivation that is influenced by various factors ranging from the context of the classroom, teaching materials, and tasks that are different from the teacher's role (Dörnyei, 2003). The attitudes taken by teachers towards language learning, teaching methods and practices, and their personality traits tend to influence students' motivation differently. Student motivation plays an important role in determining the quality of education (Effendi \& Multahada, 2017).

This finding also supports experts in educational psychology who argue that motivation greatly influences the development of students' intellectual skills which are divided into two types, internal and external stimulation (Taheri-Kharameh, Sharififard, Asayesh, Sepahvandi, \& Hajimohamad Hoseini, 2018.).Good and positive academic emotions always produce pleasure, hope, and honour, thereby reducing shame, anxiety, and anger, despair, which in the end can help improve self-esteem, self-concept, and self-efficiency in learning. Conversely, high academic motivation accompanied by the use of maximum learning can help academic emotions more positively (Valinasab \& Zeinali, 2018). Academic motivation can also be categorized as need, motivation, and other factors in maintaining individuals in the educational environment, making learners fully involved in activities to achieve achievement (liu, 2015). Students with high academic motivation tend to be more active in getting better grades and prefer to be involved in learning compared to low motivated learners (Chen \& Jang, 2010). Many studies suggest that academic motivation has a positive and significant effect on academic achievement (Tibbetts, Canning, \& Harackiewicz, 2015).

This study also confirmed the strong correlation between learning achievement and the learning model proposed by Mingzhen Bao, Lucia Lee (http://www.ncolctl.org) that there is a correlation between overall academic achievement and students' foreign language achievement at CTL and LCTL. Students who study LCTL are less nervous and more motivated than those who use CTL. Strong trends occur in integrity and attitudes towards learning situations: students at LCTL achieve a more integrative orientation and a more positive attitude towards the learning environment. Students who have integrative motivation are generally more successful in learning languages than those who are instrumental oriented. Also, students with integrative orientation have a more positive attitude towards the target language group and are more motivated to learn the language (Bao \& Lee). 
Achievement of student learning as discussed by previous researchers of course all relate to affective factors of students, namely motivation, attitude, and expectations of learning. Learning expectations of these students must be optimistic and optimal to achieve maximum performance because the good and conducive expectations among students produce high achievement. The optimal expectations of these students are also caused by the maximum provision of good processes in the classroom by the teacher as the main person in charge. In short, there is a mutualism relationship between maximizing the process of learning English in class, optimism and positivism in achieving achievement.

Thereby improving the quality of learning by optimizing collaboration in the form of collaborative team teaching has a great opportunity to produce collaborative relationships to share the burdens and responsibility in mutual planning, implementing, and evaluating process, and thus can ease the liability of teachers to achieve improved performance. Finally, the optimal learning process can contribute strong and positive student expectations in achieving better learning.

\section{CONCLUSION}

The results of this study indicate that there is a strong correlation between perceptions of collaborative team-teaching methods conducted by teachers and lecturers with motivation for student achievement. Thus the fulfilment of the standards of learning process which are carried out together with various elements involved, especially colleagues or fellow teachers and lecturers can produce positive expectations of students in achieving better learning particularly in a remote island. Thus open teachers to cope with difficulties through collaborative team teaching activities in planning, implementing, and evaluating have several positive upshots. This research has shown that this process provides two major benefits, namely easing the burden on teachers in deciding teaching strategies quickly and accurately, as well as having a positive effect on increasing student achievement motivation. This research also shows that learners who have motivation must have the following conditions, namely having a clear and highly desirable future self-image, this self and future self-image should be very possible to be realized and not contrary to the expectations of family, friends, or the surrounding environment, self-image and this future image is always activated in every process including anticipating the negative consequences of a situation that cannot be desired.

With limited data sources and research designs, further research is needed especially in terms of expanding the number of respondents and the theoretical recheck of the same participatory learning models with experiment or development designs in more specific and different settings.

\section{REFERENCES}

Alderman, M. K. (2004). Motivation for Achievement Possibilites for Teaching and Learning (2 ed.). New Jersey: Lawrence Erlbaum Associates, Inc. 
Alireza, Y., Gholamreza, G., \& Samaneh, F. (2012, March 28). Motivation and academic achievement in medical students. $J$ Educ Health Promot, 1(4). doi:10.4103/2277-9531.94412

Anwar, K. (2015). A Constructive Teaching Model in Learning Research Concept for English Language Teaching Students. International Education Studies, 8(5). doi:10.5539/ies.v8n5p62

Anwar, K., \& Arifani, Y. (2016). Task Based Language Teaching: Development of CALL. International Education Studies, Vol. 9,(No. 6.). doi:http://dx.doi.org/10.5539/ies.v9n6p168

Anwar, K., \& Wardhono, A. (2019). Students' Perception of Learning Experience and Achievement. International Journal of Instruction, 12(3), 271-288. doi:https://doi.org/10.29333/iji.2019.12317a

Anwar, K., Asari, S., Fauziyah, N., Arifani, Y., \& Suryanti, S. (2019, September). Factors Affecting Services for Computer. International Journal of Recent Technology and Engineering (IJRTE), 8(3), 7040-7047. doi:DOI:10.35940/ijrte.C5304.098319

Asari, S., Husniah, R., Ma'rifah, U., \& Anwar, K. (2019). Fostering Students' High Order Thinking Skills through the Use of Interpretation Cards. International Journal of $\begin{array}{lllll}\text { Education } \quad \& \quad \text { Literacy } & \text { Studies, } & 7(4), & \text { 17-22. }\end{array}$ doi:http://dx.doi.org/10.7575/aiac.ijels.v.7n.4p.17

Asmara, C. H., Anwar, K., \& Ribeh, M. (2016). EFL Learners' Perception toward an Outdoor Learning Program. International Journal of Education \& Literacy Studies, 4(2). doi:http://dx.doi.org/10.7575/aiac.ijels.v.4n.2p.74

Awan, R.-U.-N., Noureen, G., \& Naz, A. (2011). A Study of Relationship between Achievement Motivation, Self Concept and Achievement in English and Mathematics at Secondary Level. International Education $\quad$ Studies, 79. doi:https://doi.org/10.5539/ies.v4n3p72

Bao, M., \& Lee, L. (n.d.). Personality, motivation, and language attitudes of learners of CTLs and LCTLs. Retrieved from http://www.ncolctl.org/files/personalitymotivation.pdf

Berwick, R. (1989). Need Assessment; Language Programming: From Theory to Practice. In R.K Johnson (eds), The Second Language Curriculum, pp 48-62. New York: Cambridge University Press.

Cerino , E. S. (2014). Relationships Between Academic Motivation, Self-Efficacy, and Academic Procrastination. PSI CHI, THE INTERNATIONAL HONOR SOCIETY IN PSYCHOLOGY , 19(4). doi: 2164-8204

Chen, K. C., \& Jang, S. J. (2010). Computers in Human Behavior 26. 741-752. doi:10.1016/j.chb.2010.01.011

Conole, G. (2013). Designing for Learning in an Open World. New York: Springer. 
Covington, M. V. (1984). The Self-Worth Theory of Achievement Motivation: Findings and Implications. The Elementary School Journal, 85(1), 4-20.

Dornyei, Z. (1994). Motivation and Motivating in the Foreign Language Classroom. The Modern Language Journal, , 78, No(3), 273-284. Retrieved from http://www.jstor.org/stable/330107

Dörnyei, Z. (2003). Attitudes, orientations, and motivations in language learning: Advances in theory, research, and applications. Language learning, 53(S1), 3-32. doi:10.1111/1467-9922.53222

Effendi, W. D., \& Multahada, E. (2017). Influence of Intrinsic and Extrinsic Learning Motivation in College Students on Choice of Majors at State Universities. JURNAL PENDIDIKAN HUMANIORA, 5(1), 15-20. Retrieved from http://journal.um.ac.id/index.php/jph

Falls, I., Bahhouth, V., Chuang, C. M., \& Bahhouth, J. (2014). Factors Influencing Students' Perceptions of Online Teamwork. SAGE Open. doi: $10.1177 / 2158244014525415$

Friend, M., \& Cook, L. (2007). Interactions: Collaboration skills for school professionals. White Plains, NY: Longman.

Hamzaoui-Elachachi , H., \& Graia, W. B. (2014). Motivation in the ESP Classroom: The Case of Algerian Biomedical Engineering students. The Asian ESP Journal, 71-98. Retrieved from http://www.asian-esp-journal.com

Han, J., \& Lynch, R. (2014). The Relationship Between Perception of School Climate and Achievement Motivation among Korean Students in Grades 6 to 12 at a Selected International School in Bangkok, Thailand. Retrieved january 27, 2020, from https://pdfs.semanticscholar.org:

https://pdfs.semanticscholar.org/533a/5fd8bfd42c3cc329f36ed1e6fcac79c69daf.pdf

Hariyanto, D. D., Dewi, E. I., \& S, L. A. (2014). Hubungan Persepsi tentang Kesesuaian Harapan Orang Tua dengan Diri dalam Pilihan Studi Lanjut dengan Tingkat Stres pada Siswa Kelas XII di Kabupaten Jember. e-Jurnal Pustaka Kesehatan, 2(1), 125-131. Retrieved from https://jurnal.unej.ac.id/index.php/JPK/article/view/608/436

Johnson, M. P. (2012). Examining EFL Motivation in Japanese Engineering Students. The Asian ESP Journal Summer Edition, 8(2), 27-54. Retrieved from http://www.asianesp-journal.com

Karami, M., Pakmehr, H., \& Aghili., A. (2015). Teaching strategies and developed critical thinking disposition: Intrinsic motivation, or group feedbacks? International Journal of Educational and Psychological Researches, 1(2), 135-138. doi:DOI, $10.4103 / 2395-2296.152228$

Kharameh, Z. T., Sharififard, F., Asayesh, H., Sepahvandi, M., \& Hosein, M. H. (2018). Relationship between Academic Self-efficacy and Motivation among Medical Science Students. Journal of Clinical and Diagnostic Research . 
Klimova, B. F. (2011). Motivation for learning English at a university level. Procedia Social and Behavioral Sciences 15 (2011), 15, 2599-2603. doi:10.1016/j.sbspro.2011.04.153

Letterman, M. R., \& Dugan, K. B. (2004). Team teaching a cross-disciplinary honors course: Preparation and development. College Teaching, 52(2), 76-81.

Lim, Y. s., \& Kwiatkowski, T. (2018). Modeling integration: co-teaching basic and clinical sciences medicine in the classroom. Advances in Medical Education and Practice, 739-751. Retrieved from www.dovepress.com

liu, Y. (2015). The longitudinal relationship between Chinese high school students' academic stress and academic motivation. Learning and Individual Differences, 38, 123-126.

Murawski, W. W. (2010). Collaborative teaching in elementary schools: Making the marriage work! California: Thousand Oaks, CA: Corwin.

My Lien, T. T. (2009). Assessing the Perceptions and Difficulties of Students at COT, VNU in Making ESP Presentations. The Asian ESP Journal, 5, 78-96. Retrieved from http://www.asian-esp-journal.com

Nelson, R. M., \& DeBacker, T. K. (2008). Achievement Motivation in Adolescents: The Role of Peer Climate and Best Friends. The Journal of Experimental Education, 76(2), 170-189.

Pateșan, M. (2017). Working Together in Class. Scientific Bulletin, XXII (2), 44. doi:10.1515/bsaft-2017-0014

Rezvani, R., Pakdaman, S., \& Bigdeli., R. A. (2015). Teacher Perfectionism and Iranian English Language Learners' Motivation and Achievement. Beyond Words Vol.3, No.2, November 2015., 184-192. Retrieved from https://media.neliti.com/media/publications/231693-teacher-perfectionism-and-iranianenglis-3b7b5b61.pdf

Robinson, B., \& Schaible, R. (1995). Collaborative teaching: Reaping The benefits. College Teaching, 43(2), 57-59.

Shachar, H., \& Fischer, S. (2004). Cooperative learning and the achievement of motivation and perceptions of students in 11th grade chemistry classes. Learning and Instruction, 69-87.

Shiri, S. (2015, June 3). The Application of Podcasting as a Motivational Strategy to Iranian EFL Learners of English: A View toward Listening Comprehension. Australian International Academic Centre, 6(3). Retrieved from http://dx.doi.org/10.7575/aiac.alls.v.6n.3p.155

Taheri-Kharameh, Z., Sharififard, F., Asayesh, H., Sepahvandi, M., \& Hajimohamad Hoseini, M. (2018.). Relationship between Academic Self-efficacy and Motivation 
among Medical Science Students. Journal of Clinical and Diagnostic Research. doi:10.7860/JCDR/2018/29482.11770

Tibbetts, Y., Canning, E. A., \& Harackiewicz, J. M. (2015). Academic Motivation and Performance: Task Value Interventions. International Encyclopedia of the Social \& Behavioral Sciences, 2nd edition, 1. doi:http://dx.doi.org/10.1016/B978-0-08-09

Valinasab, S., \& Zeinali, A. (2018, November 6). The Mediational Pathway Among Academic Emotions, Self-regulated, and Academic Motivation with Academic of High School Student. International Journal of Education and Psychological Researches. Retrieved from http://www.ijepjournal.org

Vicente, A. J., Tan, T. A., \& Yu, A. R. (2018). Collaborative Approach in Software Engineering Education: An Interdisciplinary Case. . Journal of Information Technology Education: Innovations in Practice, 127-152. doi:https://doi.org/10.2894

Willey, J. M., lim, Y. s., \& Kwiatkowski, T. (2018). Modeling integration: co-teaching basic and clinical sciences medicine in the classroom. Advances in Medical Education and Practice, 739-751. Retrieved from www.dovepress.com

Zhou, G., KIM, J., \& Kerekes, J. (2011). Collaborative teaching of an integrated methods course. International Electronic Journal of Elementary Education, 3(2). Retrieved from IEJEE www.iejee.com. 